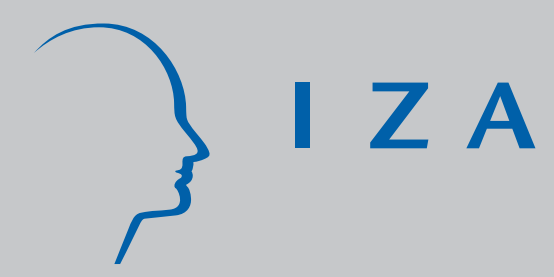

IZA DP No. 3796

Financial Development and the Distribution of Income in Latin America and the Caribbean

Gustavo Canavire-Bacarreza

Felix Rioja

October 2008 


\title{
Financial Development and the Distribution of Income in Latin America and the Caribbean
}

\author{
Gustavo Canavire-Bacarreza \\ Georgia State University \\ and IZA
}

Felix Rioja

Georgia State University

Discussion Paper No. 3796

October 2008

\author{
IZA \\ P.O. Box 7240 \\ 53072 Bonn \\ Germany \\ Phone: +49-228-3894-0 \\ Fax: +49-228-3894-180 \\ E-mail: iza@iza.org
}

\begin{abstract}
Any opinions expressed here are those of the author(s) and not those of IZA. Research published in this series may include views on policy, but the institute itself takes no institutional policy positions.

The Institute for the Study of Labor (IZA) in Bonn is a local and virtual international research center and a place of communication between science, politics and business. IZA is an independent nonprofit organization supported by Deutsche Post World Net. The center is associated with the University of Bonn and offers a stimulating research environment through its international network, workshops and conferences, data service, project support, research visits and doctoral program. IZA engages in (i) original and internationally competitive research in all fields of labor economics, (ii) development of policy concepts, and (iii) dissemination of research results and concepts to the interested public.
\end{abstract}

IZA Discussion Papers often represent preliminary work and are circulated to encourage discussion. Citation of such a paper should account for its provisional character. A revised version may be available directly from the author. 
IZA Discussion Paper No. 3796

October 2008

\section{ABSTRACT \\ Financial Development and the Distribution of Income in Latin America and the Caribbean}

One of the central concerns in Latin America and the Caribbean (LAC) has been the reduction of poverty and inequality so prevalent in the continent. Using large world samples, the literature has found that financial development increases economic growth, increases the income of the poor, and reduces inequality. This paper studies the effects of financial development on the whole distribution of income in LAC. We find that the income of the poorest quintile has not been affected by expansion in the financial system. However, we do find that financial development has had a disproportionate positive effect on the incomes of the second, third and fourth quintiles. We also find some evidence for the GreenwoodJovanovic (1991) hypothesis that this positive effect only begins after a country crosses a certain economic development threshold.

JEL Classification: $\quad$ O11, O16, G00

Keywords: distribution of income, financial development, inequality

Corresponding author:

Felix Rioja

Department of Economics

Andrew Young School of Policy Studies

Georgia State University

14 Marietta Street

Atlanta, GA 30303

USA

E-mail: frioja@gsu.edu 


\section{Introduction}

Most Latin American governments have declared growth with equity to be their overachieving goal; finance is a key instrument-one that can assist them or undermine them. Barbara Stallings and Rogerio Studart (2006).

Persistent income inequality and poverty have been fundamental issues of concern in Latin America and the Caribbean (LAC). To some degree, many political and economic experiments in the last century have been driven by the search for a system that would reduce inequality and poverty in the continent. These political and economic experiments include: heavy government intervention and protectionism, followed by privatizations and marketoriented reforms, followed recently in some countries by the undoing of market reforms and nationalization of natural resources. Among the many reforms implemented in developing countries in the last 30 years, the liberalization and expansion of financial markets has been prominent. According to Edwards (1995), LAC countries practiced "financial repression" policies from the 1940s to the 1970s. There was a significant government presence among the financial institutions with directed lending to chosen sectors and interest rate ceilings with the purpose of raising investment and growth. With the influential work of McKinnon (1973) and Shaw (1973), financial liberalization ensued starting in the mid 1970s. Financial markets expanded steadily in LAC after that period.

The effects of financial development across the world have been extensively studied in the academic literature with a general consensus that finance increases economic growth (Levine, 2005). Some authors have also begun studying how financial development affects poverty and inequality. Using data from a world-wide sample, Beck, Demirguc-Kunt and Levine (2007) find that financial development disproportionately raises the income of the poorest quintile and that it reduces income inequality. Similarly Li, Squire and Zou (1998) found that financial development lowered inequality and raised the average income of the bottom 80th percentile of the population. A study by Dollar and Kraay (2002) finds that changes in financial development only affect the income growth of the poor by raising average growth. Honohan (2004) also finds that financial depth is negatively associated with a headcount measure of poverty. ${ }^{1}$

In this paper, we focus on the experience of countries in Latin America and the Caribbean. We extend the literature in studying the effects of financial development on all income quintiles - not just the poorest. Examining the effects for the whole range of income allows

\footnotetext{
${ }^{1}$ Other research on the topic includes Clarke, Xu, and Zou (2006) and Jalialian and Kirkpatrick (2002).
} 
us to better understand the effect of financial development on overall inequality. Individuals in different income categories may have different access or use of financial services. Contrary to the world-sample results from the literature, we find that the income of the poorest quintile in LAC countries was unaffected by financial development. This finding has very important policy implications since the poor do not seem to be benefitting from or accessing the growing financial system. On the positive side, we do find that the income of the second, third and fourth quintiles disproportionately benefitted from financial expansion. Hence, finance has been successful in raising income in the middle ranges of the income distribution in LAC.

Theory does not offer a clear-cut hypothesis of the effect of finance on the income of the poor. Given their lack of collateral and scant credit histories, poor entrepreneurs may be the most affected by financial market imperfections such as information asymmetries, contract enforcement costs, and transactions costs. As a result poor entrepreneurs with good projects may receive little funding from financial markets and remain in poverty perpetuating inequality in the country (Galor and Zeira, 1993). Increased financial development in the country would serve to relax this funding constraint, particularly on the poor, and give them more access to financing. Hence, financial development would reduce poverty and inequality as well as increase growth due to the improved allocation of capital to productive projects.

Other theories (e.g., Bourginon and Verdier, 2000) propose that financial development may not reduce poverty. These theories posit that the poor rely more on informal networks for credit. Hence, financial development would only benefit the rich and raise inequality. Along these lines, Greenwood and Jovanovic (1990) propose a non-linear effect of finance on inequality. At early stages of economic development, only the rich have access to the limited financial markets, so as the economy and the financial system grow, inequality rises. Once higher levels of economic development are reached, larger segments of society can access the growing financial markets, so inequality can be reduced. Consequently, there must be some threshold level of economic development after which the incomes of poorer segments increase with expansion of financial markets. Another reason why financial development may not reduce poverty is that when liberalization is done rapidly crisis seem to follow. In the LAC case, this was due generally to liberalization without adequate expansion of prudential regulation and supervision. Resulting crisis would then increase unemployment and reduce incomes across the board.

We test these theories using data for 21 LAC countries from 1960 to 2005. We use GMM dynamic panel estimators from Arellano and Bond (1991) and Blundell and Bond (1998) to confront potential econometric pitfalls like country specific effects, endogeneity and reverse causation. The paper proceeds as follows: Section 2 describes the measures of poverty, inequality, and financial development. Section 3 discusses the hypotheses and methodology, 
then Section 4 discusses the results and Section 5 concludes.

\section{Data Description}

We use measures of poverty, inequality, and financial development that have been typically used in the literature. The United Nations Wider database is the source for all income distribution data. While the coverage extends back to 1960 in some cases, the data are a compilation of various country-level surveys that were conducted at irregular intervals. Hence, the income distribution data have gaps for various years especially prior to the 1990s.

First, we compute the average income of every quintile from the poorest (Q1) to the richest (Q5). To obtain the average income of each quintile, we multiply the income share reported by the Wider data base by the average per capita GDP and divide by 0.2. Table 1 shows the evolution of the average income by quintile in LAC in constant dollars. Income of the poorest quintile (Q1) rose from the 1960s through the 1980s, but has declined since then to about $\$ 1,165$ in the $2000-2005$ period. While this is the average for the continent, there is of course significant variation among countries. The lowest average income for Q1 in the 2000-05 period was $\$ 444$ in Guatemala and the highest was $\$ 2,578$ in Uruguay. Average incomes for quintiles Q2 and Q3 show a similar pattern to Q1 since they rose from the 1960s through the 1980s and then declined in the 1990s and 2000-05. Conversely, incomes for Q4 and Q5 (the richest) have risen in 2000-05 with respect to their 1990s averages. The average income of the rich (Q5) in the continent was $\$ 19,777$ in 2000-05 as Table 1 shows. The highest average income for the Q5 group is found in Chile at about $\$ 37,000$ and the lowest is found in Bolivia at about $\$ 8,500$.

Table 1

Income Distribution, Financial Development and Growth in LAC countries

\begin{tabular}{l|rrrrr}
\hline \hline Variable & $1960 \mathrm{~s}$ & $1970 \mathrm{~s}$ & $1980 \mathrm{~s}$ & $1990 \mathrm{~s}$ & $2000-05$ \\
\hline Income Q1 & 1,106 & 1,496 & 1,538 & 1,223 & 1,165 \\
Income Q2 & 1,991 & 2,724 & 3,119 & 2,600 & 2,516 \\
Income Q3 & 2,916 & 4,302 & 4,996 & 4,230 & 4,076 \\
Income Q4 & 4,413 & 6,582 & 7,995 & 6,516 & 6,682 \\
Income Q5 & 11,196 & 16,380 & 18,981 & 17,109 & 19,777 \\
Gini & 47.76 & 47.49 & 47.57 & 50.70 & 52.93 \\
Private Credit & 14.56 & 20.72 & 26.08 & 27.37 & 34.73 \\
Per capita growth & 2.299 & 2.309 & -0.470 & 1.124 & 0.856 \\
\hline \hline
\end{tabular}


A second variable of interest is the Gini coefficient which is a commonly used measure of inequality. ${ }^{2}$ According to Table 1, the Gini declined slightly from the 1960s to the 1980s, then rose in the 1990s and 2000-05. Inequality in LAC has risen in the last 15 years. In our most recent period 2000-05, the highest inequality levels are found in Brazil (Gini = 61.2) and the lowest in Jamaica (38.6).

Third, we measure the degree of financial development in a country using the Private Credit variable. This variable is defined as the amount of credit issued by financial intermediaries to the private sector. Private Credit is the most commonly used measure of financial development in the literature (Levine, 2005). It accounts for credit issued by bank and non-bank financial institutions, but excludes credit issued by central banks and development banks. Since it measures credit issued by all financial institutions (banks and non-banks), it should also capture credit issued by microfinance institutions which are quite important for lower income households. ${ }^{3}$ As Table 1 shows, Private Credit rose from about $15 \%$ of GDP in the 1960 s to about $35 \%$ of GDP in 2000-2005. Hence, there has been a significant expansion in the financial system in Latin America. Financial repression policies were practiced from the 1940s through the 1970s and consisted of heavy government participation in financial markets; interest rate ceilings; barriers to the establishment of new financial institutions; and credit directed to particular sectors of the economy that were deemed important by government planners (Edwards, 1995). The basis for these polices was the belief that they would encourage investment and growth. By the 1970s the work of McKinnon (1973) and Shaw (1973) became influential in promoting financial liberalization to promote growth. The effects can be seen in the Private Credit data that shows a steady increase starting in the 1970s.

To gain further perspective of the evolution of financial markets and of the inequality variables, it is useful to compare with East Asian countries which had a similar income per capita to LAC in the 1960s. Figure 1 depicts this comparison. While Private Credit in East Asia was comparable to LAC in 1965-1975, it increased by much more by 1995-2005 to over $70 \%$ of GDP. That means that financial development in East Asia is now about twice that of Latin America and the Caribbean. Regarding the Gini coefficient comparison, inequality in LAC increased, while it decreased in East Asia and it is now lower than in LAC. The data on the income of the poorest (Q1) tell of an even more dramatic comparison. The average

\footnotetext{
${ }^{2}$ The Gini coefficient is defined as a ratio. The numerator is the area between the Lorenz curve of the distribution and the uniform (perfect) distribution line. The denominator is the area under the uniform distribution line. Expressed as a percentage, the Gini coefficient ranges from 0 (perfect equality) to 1 (extreme inequality). Hence, higher values mean more inequality.

${ }^{3}$ Unfortunately, informal loans are not captured by Private Credit, but clearly they can be an important source of financing for the poor.
} 


\section{Figure 1: LAC and East Asia}
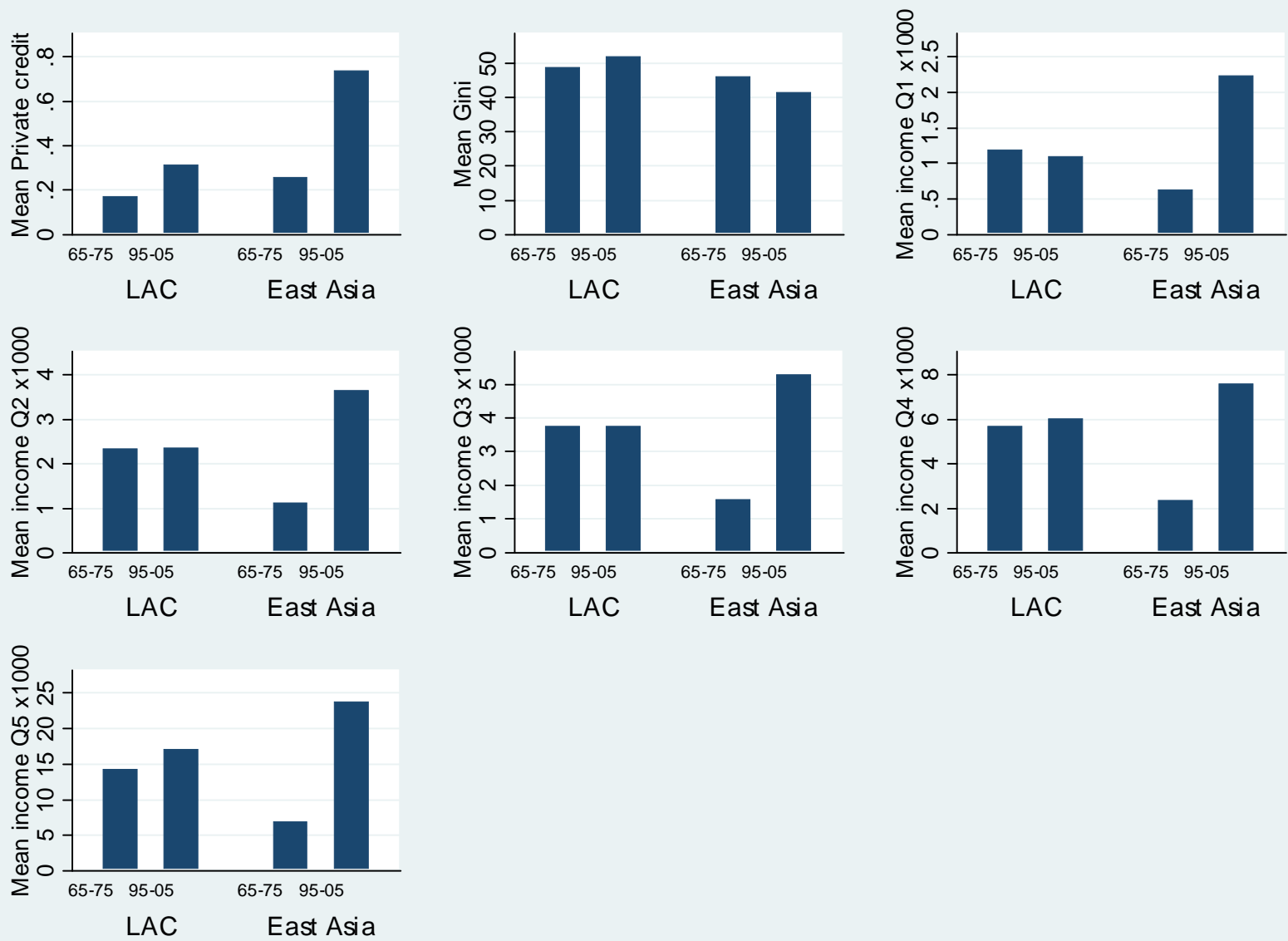

income of Q1 was lower in East Asia in 1965-1975, but has since increased significantly to around $\$ 2500$. Conversely in LAC, the average income of Q1 has decreased to around $\$ 1,200$. The average income of the remaining quintiles show a similar pattern: stagnation or small increases in LAC and large increases in East Asia.

While average incomes of all quintiles in LAC have experienced modest increases (compared to East Asia), it is our task to try to establish if changes in these incomes were to any degree driven by the expansion of the financial system after accounting for the effects of other variables that may affect incomes and inequality. We will analyze in particular if the growth rates of income and inequality variables were affected by financial development as. Data for the period 1960 to 2000 are used when available. Our units of observation are five-year non-overlapping averages of the variables as typically done in the growth literature. Five-year averages are used in this literature to smooth out the effects of short run fluctuations and focus on the long-run growth trend. While we are primarily interested in the 
long-run effects of financial development, the effects of rapid credit expansions that yielded banking or financial crisis are not entirely averaged out. Following Beck, Demirguc-Kunt and Levine's (2006) approach, we compute yearly growth rates of average income for Quintile 1 through 5 . We also compute the yearly growth rate in the Gini coefficient. Table 2 presents descriptive statistics for all the variables used in the regression analysis.

Table 2

Descriptive Statistics

\begin{tabular}{llllll}
\hline \hline Variable & Obs & Mean & Std. Dev. & Min & Max \\
\hline Private Credit & 102 & 0.2808 & 0.1652 & 0.0428 & 1.0136 \\
Growth of Income Q1 & 78 & 0.0003 & 0.0622 & -0.1781 & 0.1810 \\
Growth of Income Q2 & 74 & 0.0067 & 0.0493 & -0.1526 & 0.1874 \\
Growth of Income Q3 & 74 & 0.0101 & 0.0341 & -0.0968 & 0.1654 \\
Growth of Income Q4 & 74 & 0.0110 & 0.0298 & -0.1056 & 0.1172 \\
Growth of Income Q5 & 76 & 0.0142 & 0.0246 & -0.0681 & 0.0833 \\
Growth of Gini & 108 & 0.0011 & 0.0261 & -0.1218 & 0.0741 \\
Growth of GDP & 108 & 0.0119 & 0.0213 & -0.0615 & 0.0567 \\
Average Years of schooling & 106 & 5.1450 & 1.4938 & 1.7800 & 8.9100 \\
Log Inflation & 107 & 2.8080 & 1.5401 & -0.7208 & 7.4189 \\
Openness & 108 & 55.8477 & 41.8263 & 7.2420 & 190.9640 \\
\hline \hline
\end{tabular}

According to Table 2, the growth of income of the poor (Q1) was a very low $0.03 \%$ per year. In general, the income of higher quintiles grew faster at about $1 \%$ per year. Also, the Gini coefficient increased on average by $0.11 \%$ per year, so inequality increased on average. The list of countries is provided in the Appendix.

\section{Hypothesis and Methodology}

We follow the basic regression specification from the growth literature:

$$
y_{i, t}-y_{i, t-1}=(\alpha-1) y_{i, t-1}+\beta_{1} F D_{i, t}+\gamma X_{i, t}+\eta_{i}+\varepsilon_{i, t} .
$$

This is the typical representation for dynamic panel estimation. In this equation, $y_{i, t}$ represents, alternatively, the logarithm of the average income for each quintile and the Gini coefficient. Hence, $y_{i, t}-y_{i, t-1}$ is the growth rate in income for the relevant quintile or the 
growth rate of the Gini coefficient. The first explanatory variable is the lagged value of the dependent variable, $y_{i, t-1}$, which introduces a dynamic specification. The level of financial development, $F D_{i, t}$, is the key explanatory variable that we are interested in. The hypothesis to be tested is whether $\beta_{1}$ is positive and significantly different from zero. The vector $X_{i, t}$ includes a number of control variables. We are guided by the controls variables used in Beck, Demirguc-Kunt and Levine (2007). These variables are: the growth rate of GDP per capita (as in Dollar and Kraay, 2002), the average number of years of schooling in the population (a proxy for the stock of human capital in the population), the inflation rate (an indicator of the macroeconomic environment), and the openness of the economy (computed as exports plus imports as a share of GDP). Financial development may also affect income of a particular quintile by its effect on overall GDP per capita. Hence, it is important to control for GDP per capita to establish if there is a disproportionate effect of financial development on the income of a particular quintile (beyond its effect on GDP per capita). Finally, $\eta_{i}$ captures unobserved country-specific effects.

As described in the introduction, Greenwood and Jovanovic (1990) propose a hypothesis of a non-linear effect between financial development and inequality. In early stages of development, financial development may raise inequality as only the rich benefit. In later stages, the poor may also benefit so further financial development reduces inequality. To test this hypothesis we examine several thresholds levels in per capita GDP which we place alternatively at the 10th, 20th, 30th,...,90th percentiles of GDP per capita as in Rioja and Valev (2004). We create a dummy variable $D U M$ which equals 1 when GDP per capita is above the threshold. Then we interact this variable with financial development. The regression equation then becomes:

$$
y_{i, t}-y_{i, t-1}=(\alpha-1) y_{i, t-1}+\beta_{1} F D_{i, t}+\beta_{2}\left(D U M \times F D_{i, t}\right)+\gamma X_{i, t}+\varepsilon_{i, t} .
$$

Greenwood and Jovanovic's (1990) hypothesis would imply that $\beta_{1}<0$, but that $\beta_{1}+\beta_{2}>0$. As we do not know where the threshold lies exactly, we estimate equation 2 repeatedly varying the threshold as described above. In addition, this hypothesis has only been partly tested in the literature examining the relationship between the Gini coefficient and financial development. Since Greenwood and Jovanovic's (1990) hypothesis has implications for the overall inequality measure, it should also apply to the various income levels that make up the inequality measure. Hence, we test their hypothesis for all quintiles as well as for the Gini.

As it is well known, there are concerns of reverse causation and endogeneity in estimating equations like (1) and (2). First, the inclusion of the lagged dependent variable could bias the 
coefficients estimates. Also, there is the distinct possibility of reverse causation from quintile incomes to the real GDP per capita and other explanatory variables. To confront these problems, dynamic panel estimators developed by Arellano and Bond (1991) and Blundell and Bond (1998) have been used in the growth literature in recent years. These GMM systems estimators have become well known (see Greene, 2008), hence we will only describe them briefly here. Internal instruments are used to address the potential endogeneity. The GMM systems estimator is a stacked estimator in differences and levels. The differences equations use lagged levels as instruments. The level equations use lagged differences as instruments. There are two specification tests for this methodology. First, the Hansen J test establishes if the instruments used are valid (i.e., uncorrelated with the error terms). Second, the $\operatorname{AR}(2)$ test establishes whether there is second-order serial correlation in the errors. If both of these tests are satisfied, then the coefficient estimates are consistent.

\section{Results}

Table 3 presents the benchmark results for the estimated coefficients and their p-values which are in parenthesis. The income of the poorest quintile, Q1, is the dependent variable for the first column of results. Private Credit does not have a statistically significant effect on the income of the poor in LAC. Furthermore, even the growth in per capita GDP had no effect on the income of the poor in LAC since its coefficient is also not significant. Conversely, Beck, Demirguc-Kunt, and Levine (2007) find that financial development had a disproportionate effect on the income of the poor using a world sample. Unfortunately for the poor in LAC, we find no effect. Clearly, this result needs more discussion and elaboration which we do later in the paper. Furthermore, the coefficient on initial income is negative and statistically significant. In our setting the intepretation is that countries with the relatively low income of Q1 experienced subsequent higher growth in the income of Q1. This is akin to the convergence effect of the Solow growth model.

The average income of the second poorest quintile, Q2, is the dependent variable for the regression shown in the second column of Table 3. Private Credit has had a positive and statistically significant (at the $1 \%$ level) effect on the income of Q2. Furthermore, the coefficient on GDP per capita is 1.247 , and it is also statistically significant. An additional t-test (not reported on Table 3) reveals that we cannot reject that this coefficient is different from 1. This implies that GDP per capita increases have raised the average income of Q2 one-for-one. Consequently, the positive significant coefficient on Private Credit indicates that Private Credit has had a disproportionate positive effect on the income of this quintile. Hence, while the expansion of financial markets has not helped the poorest of the poor, it 
has helped the lower-middle income group (Q2). ${ }^{4}$

Table 3

The Effect of Financial Development on the Distribution of Income and Inequality

\begin{tabular}{lrrrrrr}
\hline \hline Variable & \multicolumn{1}{c}{$\mathrm{Q} 1$} & \multicolumn{1}{c}{$\mathrm{Q} 2$} & \multicolumn{1}{c}{$\mathrm{Q} 3$} & \multicolumn{1}{c}{$\mathrm{Q} 4$} & \multicolumn{1}{c}{ Q5 } & \multicolumn{1}{c}{ Gini } \\
\hline Private Credit & -0.102 & 0.101 & 0.058 & 0.050 & -0.059 & 0.102 \\
& $(0.805)$ & $(0.003)$ & $(0.096)$ & $(0.041)$ & $(0.392)$ & $(0.059)$ \\
Growth of GDP per cap. & -0.614 & 1.247 & 1.338 & 1.467 & 0.723 & -0.013 \\
& $(0.792)$ & $(0.015)$ & $(0.001)$ & $(0.000)$ & $(0.007)$ & $(0.955)$ \\
Initial Level of Income & -0.362 & -0.059 & -0.020 & 0.005 & 0.012 & \\
& $(0.000)$ & $(0.177)$ & $(0.426)$ & $(0.837)$ & $(0.433)$ & \\
Initial Gini & & & & & & -0.005 \\
& & & & & & $(0.000)$ \\
Constant & 3.645 & 0.390 & 0.136 & -0.070 & -0.103 & 0.138 \\
& $(0.085)$ & $(0.290)$ & $(0.526)$ & $(0.750)$ & $(0.479)$ & $(0.187)$ \\
& & & & & & \\
Obs & 75 & 71 & 71 & 71 & 73 & 102 \\
AR(2) test p-value & 0.323 & 0.432 & 0.293 & 0.409 & 0.351 & 0.604 \\
Hansen J test p-value & 0.431 & 0.745 & 0.749 & 0.185 & 0.312 & 0.298 \\
\hline \hline
\end{tabular}

Note: p-values in parenthesis correspond to robust standard errors as in Windmeijer (2005)

It is further important to interpret the size of the 0.101 coefficient on Private Credit for the Q2 regression to establish its economic significance. The country of Guatemala, for example, had the fourth smallest financial sector among the countries in our sample in 19952000; Private Credit was about 0.18 or $18 \%$ of GDP. If Guatemala expanded its financial markets to the median level of 0.26 (Dominican Republic), this would yield a rise in the income of Q2 of $0.8 \%$ per year $(0.101 \times(0.26-0.18))$. This is a sizable effect, although an expansion in the financial sector of $8 \%$ of GDP would have to be undertaken slowly over a couple of years and accompanied by adequate supervision.

Regarding the effects of financial development on quintiles Q3 and Q4, Table 4 shows that Private Credit has also had a disproportionate effect on the average income of these middle and middle-high income quintiles. While the coefficient estimate for Q3 is positive but only significant at the $10 \%$ level, the coefficient for Q4 is positive and significant at the

\footnotetext{
${ }^{4}$ The $\mathrm{AR}(2)$ test rejects the presence of second order autocorrelation. The Hansen J tests rejects that the instruments are correlated with the errors.
} 
$5 \%$ level. Note that the coefficients in the Q3 and Q4 regressions are smaller in magnitude than that for the Q2 regression. Hence, the positive effect of Private Credit is larger in the low-middle income quintile (Q2). Also, note that the coefficient on the Growth of GDP per capita for both Q3 and Q4 regressions is not significantly different from $1 .{ }^{5}$ This means that the increase in GDP per capita in the economy raised incomes in Q3 and Q4 one-for-one and that Private Credit had a positive effect beyond its effect on GDP per capita.

Next, we examine the regression for the richest quintile Q5. While the growth of GDP per capita raised the income of the rich, the evidence does not support a disproportionate effect of financial development as the estimated coefficient is not statistically significant. Finally, the last column of Table 3 reports the regression with the Gini coefficient as the dependent variable. The estimated coefficient for Private Credit is positive and significant at the $10 \%$ level. The positive effect indicates that financial development may have increased inequality in LAC. Recall that the Gini coefficient summarizes the whole income distribution in one number which is not an easy task. Given that financial development appears to not have affected the poorest and the richest quintiles, but affected the low-middle, middle, and middle-high income groups to different degrees, it is possible that effect of Private Credit on the Gini yields higher inequality (or no effect if one strictly applies the standard $5 \%$ level of significance).

We next proceed to test the Greenwood and Jovanovic hypothesis by estimating equation (2). As described above, we created a dummy variable at several discrete intervals of the GDP per capita distribution. We run regressions for each potential threshold. We find evidence of a non-linear effect that seems to roughly start when the threshold is placed at the 30th percentile of the distribution. For conciseness, we only report the results using this 30th percentile threshold; the results for other thresholds are available from the authors. Table 4 describes these results. The regressions are estimated using two controls sets. The "Simple Control Set" includes the lagged level of income (or lagged Gini for the inequality regression) and the growth rate of GDP per capita. The "Full Control Set" includes the lagged dependent variable, the growth rate of GDP per capita, schooling attainment, the log of inflation, and trade openness. Consider first the regression for the poorest quintile (Q1). Again there is no evidence of an effect of financial development on the income of the poor even accounting for a potential non-linear effect. Next consider the regression for the lowmiddle income quintile (Q2) shown on the third and fourth columns. Private credit does not have a statistical significant effect when below the threshold. However, once the threshold is passed, the effect is statistically significant and positive. The estimated coefficient reported for $P C+(D U M \times P C)$ is basically $\beta_{1}+\beta_{2}$ from equation (2) and it is 0.235 , which is larger

\footnotetext{
${ }^{5}$ This is again acertained with additional t-tests not shown in Table 4.
} 
than its counterpart from the regression without a threshold discussed previously.

The results for Q3 and Q4 are similar. There is a positive significant effect above the threshold as Greenwood and Jovanovic's (1991) theory predicts. Below the threshold, however, we find that there is no statistically significant effect which does not agree with Greenwood and Jovanovic (1990). However, note that the signs of the coefficients are uniformly negative as Greenwood and Jovanovic would predict.

The regression for the richest quintile Q5 again indicates no effect of financial development on the rich as in the previous table. This is also the case for the Gini coefficient which does not support the Greenwood and Jovanovic hypothesis directly. Again, however, one must note that since the middle quintiles appear to exhibit non-linear effects of different magnitudes pulling the distribution or Gini in different directions, the non-effect on Gini may be explained as it hides important changes occurring in some quintiles of the distribution. 


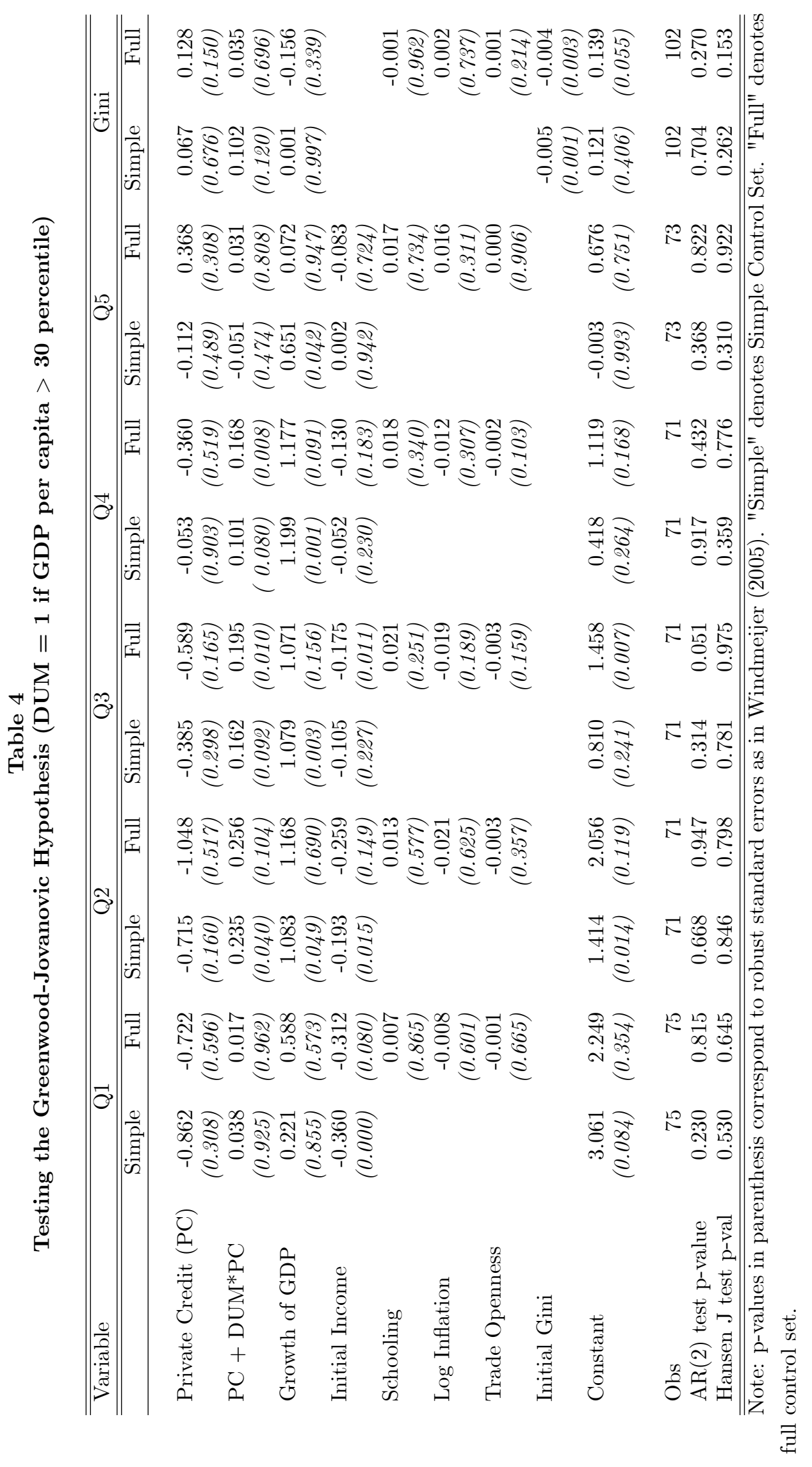




\section{Discussion of Results and Conclusions}

The expansion of financial markets has received quite a bit of attention in Latin America and the Caribbean from governments and multilateral organizations. Larger financial systems have been found to increase growth and reduce poverty and inequality in large world samples. We studied the effect of financial development on the distribution of income in LAC. We find that financial development has not had an effect on the incomes of the poorest quintile. Conversely, it has a positive and disproportionate effect on the incomes of quintiles Q2, Q3, and Q4. Given the serious concern in LAC countries with reduction of extreme poverty, it is important to understand why financial services may not be reaching the poorest segments of society.

The poor are likely to use microfinance institutions, rather than full-fledged commercial banks or other financial institutions. According to Bouillon and Tejerina (2007), the effects of microfinance have been mixed with a positive effect on income found in Brazil and Peru, but a zero or negative effect found in Bolivia and Chile. These mixed results from microlevel studies may explain why there seems to be no effect at the aggregate level as well as in our paper. According to a World Bank study, microfinance institutions reach the moderate poor, but do not reach the extremely poor (Sebastad and Cohen, 2000). Navajas and Tejerina (2007) estimate that the average loan size of these institutions in LAC in 2005 was about $\$ 1,000$, which is likely out of the question for the extremely poor. In addition, the poor may have difficulty getting financing even from some microlending institutions since many of them may require collateral to make a loan. Hernando De Soto's (2000) well known hypothesis is that lack of land titling implies that it cannot be used as collateral to borrow from banks, so investments that may have raised the incomes of poor farmers are curtailed. While micro-level studies of land titling programs in Argentina, Nicaragua, and Peru show positive effects on school attendance and health, they find no effect on credit access which was the primary purpose of these polices (Bouillon and Tejerina, 2007).

It is possible that the poor simply do not have enough access to financial services, or that they only have access to a subset of financial services. Here we focused on a financial size measure, but the more relevant measure for the poor may be access and use of financial services. Unfortunately, data on this has only been recently collected and it is only available for a recent period (see Beck, Demirgüç-Kunt, and Martinez Peria, 2006). The poor's low level of access may be also due to their location: a large share of the poor live in rural areas where banking services have trouble reaching. Yet another possibility is that their demand for financial services is low. Why the poor are not benefitting from expanded financial services remains a question of interest for future research. 
The positive findings of the paper are that financial development seems to have succeeded in raising the income of individuals in the middle income ranges (Q2 to Q4). This is an encouraging finding. In particular, the effect for the low-middle quintile Q2 seems to be even larger than that in Q3 and Q4. Hence, the second poorest quintile has been able to access financial markets and benefit, perhaps due to living in urban areas. In summary, the efforts placed on developing financial markets to help a country prosper appear to have yielded some positive effects. Much work remains in understanding why the poorest in LAC have not yet benefitted. 


\section{References}

[1] Arellano, M. and S. Bond. (1991). "Some Tests of Specification for Panel Data: Monte Carlo Evidence and an Application to Employment Equations," Review of Economic Studies 58, 277-297.

[2] Beck, T., Demirgüç-Kunt, A. and Levine, R. (2007). "Finance, Inequality and the Poor," Journal of Economic Growth, Volume 12, Number 1

[3] Beck, T., Demirgüç-Kunt, Maria Soledad Martinez Peria. (2006). "Reaching out: Access to and use of banking services across countries." Working Paper.

[4] Blundell, R. and S. Bond. (1998). "Initial conditions and moment restrictions in dynamic panel data models." Journal of Econometrics, 87(1), 115-143.

[5] Bouillon, Cesar P. and Luis Tejerina. (2007). "Do We Know What Works? A Systematic Review of Impact Evaluations of Social Programs in Latin America and the Caribbean." Inter-American Development Bank.

[6] Bourguignon, F. and Verdier, T. (2000), "Oligarchy, democracy, inequality and growth", Journal of Development Economics, vol. 62, pp. 285-313.

[7] Clarke, G. L.C. Xu and Zou, H. (2006). "Finance and Income Inequality: What Do the Data Tell Us?" Southern Economic Journal 72, 578-96.

[8] Dollar, David and Aart Kraay (2002): "Growth is good for the poor". Journal of Economic Growth 7, 3, 195-225.

[9] De Soto, Hernando. (2000). The Mystery of Capital: Why Capitalism Triumphs in the West and Fails Everywhere Else. Basic Books.

[10] Edwards, Sebastian. (1995). Crisis and Reform in Latin America: From Despair to Hope. A World Bank book. New York: Oxford University Press.

[11] Galor, O. and Zeira, J. (1993). "Income Distribution and Macroeconomics," Review of Economic Studies, Blackwell Publishing, vol. 60(1), pages 35-52.

[12] Greene, William. (2008). Econometric Analysis, Prentice Hall, 6th Edition.

[13] Greenwood, J. and Jovanovic B. (1990), "Financial Development, Growth, and the Distribution of Income," Journal of Political Economy, 98 (5): 1076-1107. 
[14] Honohan, Patrick. (2004). "Financial Development, Growth and Poverty: How Close are the Links?" World Bank Policy Research Working Paper 3203.

[15] Jalilian, Hossein and Colin Kirkpatrick. (2002). "Financial development and poverty reduction in developing countries." International Journal of Finance $\mathcal{E}$ Economics. Volume 7, Issue 2, Pages: 97-108.

[16] Levine, R. (2005). "Finance and Growth: Theory and Evidence," In Handbook of Economic Growth, Eds. Philippe Aghion and Steven Durlauf, Amsterdam: North-Holland Elsevier Publishers.

[17] Li, Hongyi, Lyn Squire and Heng-fu Zou,.(1998). "Explaining International and Intertemporal Variations in Income Inequality", Economic Journal, 108(1): 26-43.

[18] McKinnon, Ronald. (1973). Money and Capital in Economic Development. Washington, D.C.:Brookings Institution.

[19] Navajas, Sergio and Luis Tejerina. (2007) "Microfinance in Latin America and the Caribeean: How Large is the Market?" Inter-American Development Bank, Sustainable Development Department.

[20] Rioja, Felix and Neven Valev. (2004). "Does one size fit all?: a reexamination of the finance and growth relationship," Journal of Development Economics 74: 429-447.

[21] Sebstad, Jennifer and Monique Cohen. (2000). Microfinance, Risk Management and Poverty. AIMS Project Working Paper. USAID Office of Micronterprise Development, Washington, DC.

[22] Shaw, Edward. (1973). Financial Deepening and Economic Development. New York: Oxford University Press.

[23] Stallings, Barbara and Rogerio Studart (2006). Finance for Development: Latin America in Comparative Perspective. Washington, D.C.: Brookings Institution Press.

[24] Tejerina, Luis, Cesar Bouillon, and Edgardo Demaestri, eds. (2006). Financial Services and Poverty Reduction in Latin America and the Caribbean. Inter-American Development Bank.

[25] Windmeijer, F. (2005). "A finite sample correction for the variance of linear efficient two-step GMM estimators." Journal of Econometrics 126: 25-51. 


\section{Appendix}

\section{Country List}

Argentina

Bolivia

Brazil

Chile

Colombia

Costa Rica

Dominican Rep.

Ecuador

El Salvador

Guatemala

Honduras

Jamaica

Mexico

Nicaragua

Panama

Paraguay

Peru

Trinidad and Tobago

Uruguay

Venezuela 